${ }^{5}$ Hypertension Detection and Follow-up Program Cooperative Group. Five-year findings of the hypertension detection and follow-up program. II. Mortality by race, sex and age. F AMA $1979 ; 242: 2572-7$.

6 Management Committee. Initial results of the Australian Therapeutic Trial in Mild Hypertension. Clinical Science 1979;57:449-52s.

7 Management Committee. The Australian Therapeutic Trial in Mild Hypertension. Lancet $1980 ; 1: 1261-7$.

${ }^{8}$ Breckenridge A, Dollery CT, Parry EHO. Prognosis of treated hypertension. Changes in life expectancy and causes of death between 1952 and 1967. $Q \mathcal{F}$ Med 1970;39:411-29.

${ }^{9}$ Beevers DG, Fairman MJ, Hamilton M, Harpur JE. The influence of antihypertensive treatment over the incidence of cerebral vascular disease. Postgrad Med f 1973;49:905-7.

${ }^{10}$ Berglund G, Wilhelmsen L, Sannerstedt R, et al. Coronary heart-disease after treatment of hypertension. Lancet $1978 ; 1: 1-5$.

${ }_{11}$ Medical Research Council Working Party on Mild to Moderate Hypertension. Randomised controlled trial of treatment for mild hypertension: design and pilot trial. Br Med f 1977; ; :1437-40.

12 Barlow DH, Beevers DG, Hawthorne VM, Watt HD, Young GAR. Blood pressure measurement at screening and in general practice. $\mathrm{Br}$ Heart $\mathcal{F} 1977 ; 39: 7-12$.

${ }^{13}$ Hart JT. Semicontinuous screening of a whole community for hypertension. Lancet 1970;ii:223-6.

${ }^{14}$ Coope J. A screening clinic for hypertension in general practice. $\mathcal{F} R$ Coll Gen Pract 1974;24:161-6.

\section{Uraemic pruritus}

Pruritus is not a feature of acute renal failure but is common in severe chronic renal failure, the reported ${ }^{1-3}$ incidence being as high as $86^{\%} \%$. Many factors have been incriminated. Patients commonly have a dry skin (xerosis), and this may contribute to the pruritus. ${ }^{2}$ The xerosis may be related to the atrophy of the sebaceous glands ${ }^{4}$ and the eccrine sweat glands that occurs in uraemia. ${ }^{5}$ The disturbances of calcium and phosphorus metabolism in chronic renal failure have also been implicated, ${ }^{16-9}$ while other possible factors include the proliferation of mast cells in the skin of some patients with uraemia, ${ }^{10}$ the high serum concentrations of magnesium, ${ }^{11}$ and an association with uraemic neuropathy. ${ }^{12}$ With so many possibilities the only certainty is that the mechanism of uraemic pruritus remains unknown.

Regular and intensive haemodialysis is said to cure or improve pruritus in many patients, ${ }^{13}{ }^{14}$ but some reports ${ }^{1}$ have put the proportion relieved of their symptoms as low as $14 \%$. Sometimes the pruritus may worsen or appear for the first time after starting maintenance haemodialysis. In some (but not all) patients with severe secondary hyperparathyroidism subtotal parathyroidectomy may dramatically improve or cure intractable pruritus. ${ }^{6-8}$ Not all patients with severe secondary hyperparathyroidism have pruritus, however, ${ }^{6}$ and many who have intractable pruritus do not have severe secondary hyperparathyroidism. Uraemic pruritus may be helped by simple measures such as skin emollients, systemic antihistamine preparations, and minor tranquillisers. ${ }^{15}$ Very low protein diets may help ${ }^{16}$ and so may sauna baths. ${ }^{17}$ Recently a whole variety of treatments have been tried in patients being treated with maintenance haemodialysis with intractable pruritus; but the best answer is renal transplantation with a good functioning graft.

Among the empirical treatments that have been commended is regular intravenous heparin for several weeks; good results were claimed but these were uncontrolled observations. ${ }^{18} \mathrm{~A}$ double-blind trial comparing intravenous lignocaine with placebo saline during haemodialysis showed an improvement in the patients given the drug. ${ }^{3}$ Oral cholestyramine gave good results in one controlled trial ${ }^{19}$ but not in another ${ }^{20}$ and cholestyramine carries a possible risk of inducing or aggravating a metabolic acidosis in uraemic patients. ${ }^{21}$ Ultraviolet phototherapy has also been tried ${ }^{22}$ and was effective in a controlled trial..$^{22}$

Pruritus is a notoriously difficult symptom to assess, and in all these trials with lignocaine, cholestyramine, and ultraviolet phototherapy the numbers were small; but these treatments may be worth trying in patients with intractable itching. A final note of caution: patients with severe uraemia are not immune from other causes of pruritus, such as scabies.

1 Young AW, Sweeney EW, David DS, et al. Dermatologic evaluation of pruritus in patients on hemodialysis. NY State $f$ Med 1973;173: 2670-4.

2 Rosen T. Uremic pruritus: a review. Cutis $1979 ; 23: 790-2$.

${ }^{3}$ Tapia L, Cheigh JS, David DS, et al. Pruritus in dialysis patients treated with parenteral lidocaine. N Engl f Med 1977;296:261-2.

4 Rosenthal SR. Uremic dermatitis. Archives of Dermatology and Syphilology $1931 ; 23: 934-45$.

${ }^{5}$ Cawley EP, Hoch-Ligeti C, Bond GM. The eccrine sweat glands of patients in uremia. Arch Dermatol $1961 ; 84: 889-97$.

${ }^{6}$ Hampers CL, Katz AI, Wilson RE, Merrill JP. Disappearance of "uremic" itching after subtotal parathyroidectomy. $N$ Engl $\mathcal{F}$ Med $1968 ; 279: 695-7$.

${ }^{7}$ Kleeman CR, Massry SG, Popovtzer MM, Makoff DL, Maxwell $\mathrm{MH}$, Coburn JW. The disappearance of intractable pruritus after parathyroidectomy in uremic patients with secondary hyperparathyroidism. Trans Assoc Am Physicians 1968;81:203-12.

${ }^{8}$ Massry SG, Popovtzer MM, Coburn JW, Makoff DL, Maxwell $\mathrm{MH}$, Kleeman CR. Intractable pruritus as a manifestation of secondary hyperparathyroidism in uremia. Disappearance of itching after subtotal parathyroidectomy. $N$ Engl F Med 1968;279:697-700.

9 Massry SG, Coburn JW, Hartenbower DL, et al. Calcium and magnesium content in skin of patients with uremia and calcemic disorders. Clinical Research 1971;19:188.

${ }^{10}$ Neiman RS, Bischel MD, Lukes RJ. Uraemia and mast-cell proliferation. Lancet 1972 ; : 959 .

${ }^{11}$ Graf H, Kovarik J, Stummvoll HK, Wolf A. Disappearance of uraemic pruritus after lowering dialysate magnesium concentration. $\mathrm{Br} \mathrm{Med} f$ 1979 ;ii:1478-9.

12 Raskin NH, Fishman RA. Neurologic disorders in renal failure (second of two parts). N Engl F Med 1976;294:204-10.

${ }^{13}$ Hampers CL, Schupak E, Lowrie EG, Lazarus JM. Long-term hemodialysis: the management of the patient with chronic renal failure. $2 \mathrm{nd}$ ed. New York: Grune and Stratton, 1973.

${ }^{14}$ Curtis JR, Williams GB. Clinical management of chronic renal failure. London: Blackwell, 1975.

15 Tapia L. Pruritus on hemodialysis. Int f Dermatol 1979;18:217-8.

${ }^{16}$ Boulton-Jones JM, Sissons JGP, Harrison ER. Itching in renal failure. Lancet $1974 ; \mathrm{i}: 355$.

17 Snyder D, Merrill JP. Sauna baths in the treatment of chronic renal failure. Trans Am Soc Artif Intern Organs 1966;12:188-92.

18 Yatzidis $\mathrm{H}$, Digenis $\mathrm{P}$, Tountas $\mathrm{C}$. Heparin treatment of uremic itching F $A M A 1972 ; 222: 1183$.

${ }^{19}$ Silverberg DS, Iaina A, Reisin E, Rotzak R, Eliahou HE. Cholestyramin in uraemic pruritus. $\mathrm{Br} M e d \mathcal{F} 1977 ; \mathrm{i}: 752-3$.

20 Van Leusen R, Lojenga JCK, Ruben ATh. Is cholestyramine helpful in uraemic pruritus? $\mathrm{Br}$ Med $\mathcal{7} 1978$; :918-9.

21 Wrong OM. Cholestyramine in uraemic pruritus. Br Med 7 1977;i:1662.

22 Gilchrest BA. Ultraviolet phototherapy of uremic pruritus. Int $\mathcal{F}$ Dermatol 1979;18:741-8.

23 Shultz BC, Roenigk HH. Uremic pruritus treated with ultraviolet light. fAM $A$ 1980;243:1836-7.

\section{Sterilisation of mentally retarded minors}

Severe mental handicap in a child is always a heavy burden for parents, but the circumstances are especially distressing when a girl is approaching the reproductive years. The risk of pregnancy is greater now than in the past, when more of these girls were cared for in single-sex institutions. There is an understandable concern to protect the youngster from pregnancy, and the parents may well seek medical advice and help. Some form of contraception may be offered, but at this age and in these circumstances none is really satisfactory. The two obvious choices-an intrauterine device and an injectable 